\title{
Studies on Hepato and Renal Toxicity of Cadmium on Normal and Protein Malnourished Rats
}

\section{Syed Saleem Husain*}

Faculty of Applied Medical Sciences, Jazan University, Jazan, Saudi Arabia

\begin{abstract}
Cadmium is an established toxic metal with its ability to accumulate in blood, liver and kidney. It adversely affects the renal cortex and ultimately leads to the renal failure. It has been reported that deficiency of certain dietary components affects cadmium toxicity. Present study was designed to evaluate the cadmium toxicity (50 ppm in drinking water) in protein malnourished group (8\%) and on normal protein (21\%) diet groups. It was found that $\mathrm{Cd}$ exposure led to marked elevation in alkaline phosphatase, acid phosphatase, glutamic pyruvic transferase, glutamic oxaloacetic acid transferase with significant increase in protein malnourished group ( $p 0.005)$.
\end{abstract}

Same trend of result was noted in urinary concentration of alpha amino acid, albumin, total protein and glucose Results were more significant ( $p$ 0.001) in malnourished animals. However, hepatic and renal enzymes showed depletion in all groups. There was marked increase in serum enzymes GOT, GPT, alkaline phosphatase, acid phosphatase in low protein diet $+C d(p 0.001)$.

Hence present findings strongly support that protein under-nutrition predisposes the organism to the deleterious effects of cadmium toxicity.

Keywords: Cadmium; Protein malnourishment; Renal toxicity; Hepato toxicity

\section{Introduction}

Various metals, in trace amounts, are essential for proper biological functioning. However, there are many heavy metals that are toxic and exposure to their high intake may result in serious adverse effects on health. Cadmium (Cd) is one of the most toxic pollutants in environment. Accumulation of $\mathrm{Cd}$ in blood affects the kidney and liver. The toxicity of cadmium is much affected by deficiency of certain dietary components.

Here we propose to study the effect of protein malnutrition on cadmium toxicity in albino rats. Such a study may be of help to safeguard the health of industrial workers as well as public at large.

An enteropathy has been observed in patient with Itai-Itai disease [1] and in Cadmium fed experimental animals [2,3]. It appears that under given conditions, a critical concentration of cadmium in the mucosal cells, produces structural damage, accompanied by marked changes in absorption of cadmium and other dietary components [4].

Kidney and liver are most affected by cadmium toxicity. The critical organs in man with respect to cadmium metabolism appear to be the kidney. Friberg et al. postulated that when the concentration of cadmium reaches a critical level $(200 \mu \mathrm{g} / \mathrm{g})$ in the renal cortex renal tubular damage occurs [5]. Alteration in antioxidant defense system in the rat testes was found with Cd exposure [6]. Studies showed toxic nephropathy might be detectable in an early stage by assay of the enzymes in urine. Cd exposure leads to decrease in glutamate, aspartate, glutamine, GABA and taurine content of rat striatum [7]. Cadmium chloride $\left(\mathrm{CdCl}_{2}\right)$, administered during gestation period on female wistar rats resulted in decrease in body weight gain and induced hepatotoxicity [8]. Glomerular injury is suggested by increased activities of ACP in urine and injury to proximal tubules by elevation of ALP, the main target organs being kidney and liver [9].

Vitamin D-deficient diet on chronic cadmium exposure in rats might lead to adverse effects [10]. Previously, it was found that cadmium chloride, $0.25 \mathrm{Cd} / \mathrm{kg}$ for 5 days a week, decreased alkaline phosphatase activity of the renal cortex at 23rd weeks [11], and there was a decrease in the capacity to reabsorb glucose, together with considerable proteinuria and excretion of cadmium $[12,13]$. Wilson induced anemia in rats with a cadmium diet; increase in eosinophils and reticulocytes with hyperplastic bone marrow were also found [2]. Marked decrease in hemoglobin was found in rats, treated with $50 \mathrm{ppm} \mathrm{Cd}$, in drinking water, Cadmium created a state of iron deficiency without any blockage in hemoglobin synthesis or erythropoietic activity [14].

It has been proved by many researchers that cadmium is a potent and cumulative toxic metal. Its toxic effects on experimental animals as well as human subjects have been well studied. It is also known that the nutritional status of animal is a significant factor in determining the degree of cadmium poisoning.

Protein malnutrition is an uncontrolled public health problem, particularly in developing countries and nutritional factors are known to play a great role in individual susceptibility to the neurotoxic effects of environmental chemicals [15]. Nutritional deficiencies are known to alter the response of the organism to the environmental toxicant in a manner different to that observed in the nutritional adequate state. Same type of study is done in rhesus monkeys (Macaca mulatta) in relation to protein calorie malnutrition [15]. The vitamin D-deficient diet decreased serum concentration of vitamin $\mathrm{D}$, but it did not affect the metabolism of the kidney or bone. Cadmium treatments alone induce a decrease in serum concentration of vitamin $\mathrm{D}$, as well as renal dysfunction, renal anemia, and abnormal bone metabolism [10].

*Corresponding author: Syed Saleem Husain, Faculty of Applied Medical Sciences, Jazan University, Jazan, Saudi Arabia, E-mail: drsaleemsaim@gmail.com

Received August 07, 2013; Accepted September 28, 2013; Published Octobe 03, 2013

Citation: Husain SS (2013) Studies on Hepato and Renal Toxicity of Cadmium on Normal and Protein Malnourished Rats. J Material Sci Eng 2: 129. doi:10.4172/2169-0022.1000129

Copyright: (c) 2013 Husain SS. This is an open-access article distributed unde the terms of the Creative Commons Attribution License, which permits unrestricted use, distribution, and reproduction in any medium, provided the original author and source are credited. 
Hence a long term study (120 days) was conducted in growing rats exposed to cadmium (50 ppm, in drinking water). The effects were assessed in normal (21\% protein diet) and protein malnourished $(8 \%$ protein diet).

\section{Materials and Methods}

All chemicals/ reagents used for these experiments were of high quality research grade. All major chemicals were purchased from Sigma Chemical Co. (USA) and olive oil was purchased from the local supplier. Biochemical estimations were carried by using kits, supplied by Bio Lab Diagnostic Pvt. Ltd.

\section{Experimental animals}

160 weaned male rats of a wistar-derived strain, about 25-35gm, were randomly allocated into four groups of 40 rats in each: Group (I) $21 \%$ protein diet + drinking water (control), (II) $21 \%$ protein diet + drinking water (Cd, $50 \mathrm{ppm}$ ), (III) $8 \%$ protein diet + drinking water (control) and (IV) $8 \%$ protein diet + drinking water (Cd, $50 \mathrm{ppm}$ ).

The animals were fed with standard Wetherholtz diet, had free access to water under well ventilated condition of $12 \mathrm{~h}$ light cycle. The animals were adapted to laboratory condition for 7 days prior to the experiments. Investigations using experimental animals were conducted in accordance to the Organization for Economic Cooperation and Development guidelines no. 407 (OECD, Paris, 1993). The studies were performed with the approval of Institutional Animal ethics committee (IAEC).

\section{Biochemical parameters}

Experiments were conducted to study mostly hepatic and renal toxicity. The following parameters were chosen for assessing the hepatotoxicity: Glutamic Pyruvic Transaminase (GPT) and Glutamic Oxaloacetic Transaminase (GOT). While for renal toxicity, the following parameters were carried out: Alkaline Phosphatase (ALP), Acid Phosphatase (ACP), total protein content, total alpha amino acids, albumin and glucose. These parameters were assessed in urine samples, collected at monthly intervals. In liver, kidney and serum the four enzymes (GPT, GOT, ALP and ACP) and total protein content were estimated. Albumin estimation in serum and glucose in whole blood was done by using manufacturer's protocol. The parameters in tissue were done at the end of exposure period i.e. 120 days after sacrificing the animals by decapitation.

\section{Statistical analysis}

All the experimental results were expressed as the mean \pm standard deviation. Unpaired T-test and one way analysis of variance (ANOVA) with subsequent Tukey's test were used to detect further difference between groups respectively, values of $\mathrm{p}<0.05$ were considered significant.

\section{Results}

\section{Biochemical estimations}

Urinary analysis: The activity and daily excretion of alkaline phosphatase (Table 1), Acid phosphatase (Table 2), Glutamic Pyruvic Transferase (GPT) (Table 3), Glutamic Oxaloacetic Transferase (GOT) (Table 4) in urine of $\mathrm{Cd}$ exposed rats of both dietary groups were significantly enhanced from day 30 of exposure onwards. These effects were generally more marked in the protein malnourished animals; here data of 120 days are shown. $(\mathrm{p}<0.005)$.

The urinary concentration of alpha-amino acids (Table 5), Albumin (Table 6), total protein (Table 7) and glucose (Table 8) was significantly enhanced in the Cd exposed animals of both the dietary groups, from day 30 of exposure onwards but the effect was more marked in the protein malnourished animals. The daily excretion was also significantly enhanced from day 30 to 120 of Cd exposure in the

\begin{tabular}{|c|c|c|c|c|c|c|c|c|}
\hline \multirow{3}{*}{ Treatment } & \multicolumn{4}{|c|}{ n mole p-nitro phenol formed $/ \mathrm{ml}$ of urine } & \multicolumn{4}{|c|}{ n mole p-nitro phenol formed/ml/day/rat } \\
\hline & \multicolumn{4}{|c|}{ Days } & \multicolumn{4}{|c|}{ Days } \\
\hline & 30 & 60 & 90 & 120 & 30 & 60 & 90 & 120 \\
\hline Normal diet & $463.02 \pm 42.32$ & $551.82 \pm 5.29$ & $530.48 \pm 6.77$ & $520.35 \pm 6.89$ & $1393 \pm 122$ & $2436 \pm 21$ & $2466 \pm 20$ & $2420 \pm 18$ \\
\hline \multirow{2}{*}{ Normal diet $+\mathrm{Cd}$} & $565.49 \pm 16.51$ & $760.82 \pm 7.9$ & $675.02 \pm 7.73$ & $645.50 \pm 7.90$ & $1626 \pm 57$ & $3079 \pm 76$ & $3279 \pm 87$ & $3000 \pm 25$ \\
\hline & $(\uparrow 22)^{\mathrm{a} *}$ & $(\uparrow 38)^{\mathrm{a} * *}$ & $(\uparrow 27)^{\mathrm{a} * *}$ & $(\uparrow 24)^{a} *$ & $(\uparrow 17)^{\mathrm{a} *}$ & $(\uparrow 26)^{a * *}$ & $(\uparrow 33)^{\mathrm{a} * * *}$ & $(\uparrow 24)^{a} * *$ \\
\hline Low protein diet & $416.55 \pm 50.78$ & $601.1 \pm 3.01$ & $592.83 \pm 9.76$ & $535.75 \pm 9.80$ & $527 \pm 46$ & $820 \pm 16$ & $828 \pm 23$ & $810 \pm 15$ \\
\hline \multirow{2}{*}{ Low protein diet $+\mathrm{Cd}$} & $579.0 \pm 8.38$ & $787.44 \pm 2.0$ & $847.75 \pm 1.58$ & $712.55 \pm 1.60$ & $643 \pm 23$ & $976 \pm 5$ & $1217 \pm 26$ & $1093 \pm 8$ \\
\hline & $(\uparrow 39)^{b * *}$ & $(\uparrow 31)^{\mathrm{b} * *}$ & $(\uparrow 43)^{b * * *}$ & $(\uparrow 33)^{b * *}$ & $(\uparrow 22)^{\mathrm{b} * *}$ & $(\uparrow 19)^{b *}$ & $(\uparrow 47)^{\mathrm{b} * * \star}$ & $(\uparrow 35)^{b * * *}$ \\
\hline
\end{tabular}

Values represent mean \pm SE of six rats; Statistical evaluation by one-way ANOVA followed by LSD comparison; a=Compared to normal diet control, b= Compared to low protein diet control; $p^{*}=<0.05 ;{ }^{* *}=0.01 ;{ }^{* *}=<0.001 ; \uparrow=$ increase.

Table 1: Effect of $\mathrm{Cd}$ on urine levels of alkaline phosphatase in normal and protein malnourished rats (values in parentheses represent \% change).

\begin{tabular}{|c|c|c|c|c|c|c|c|c|}
\hline \multirow{3}{*}{ Treatment } & \multicolumn{4}{|c|}{ n mole p-nitro phenol formed $/ \mathrm{ml}$ of urine } & \multicolumn{4}{|c|}{ n mole p-nitro phenol formed/ml/day/rat } \\
\hline & \multicolumn{4}{|c|}{ Days } & \multicolumn{4}{|c|}{ Days } \\
\hline & 30 & 60 & 90 & 120 & 30 & 60 & 90 & 120 \\
\hline Normal diet & $172.55 \pm 13.13$ & $154.51 \pm 5.12$ & $156.81 \pm 5.53$ & $160.75 \pm 5.60$ & $961 \pm 103$ & $741 \pm 35$ & $773 \pm 27$ & $820 \pm 29$ \\
\hline \multirow{2}{*}{ Normal diet + Cd } & $151.29 \pm 17.46$ & $137.0 \pm 3.2$ & $191.31 \pm 3.03$ & $184.86 \pm 3.42$ & $788 \pm 80$ & $800 \pm 52$ & $1046 \pm 43$ & $955 \pm 40$ \\
\hline & $(\downarrow 13)^{\mathrm{a} *}$ & $(\downarrow 11)^{\mathrm{a} * *}$ & $(\uparrow 22)^{a * *}$ & $(\uparrow 15)^{\mathrm{a} *}$ & $(\downarrow 18)^{\mathrm{a} *}$ & $(\uparrow 8)^{\mathrm{a} * *}$ & $(\uparrow 35)^{\mathrm{a} * * *}$ & $(\uparrow 16)^{\mathrm{a} * *}$ \\
\hline Low protein diet & $160.09 \pm 19.13$ & $60.05 \pm 2.5$ & $63.45 \pm 2.39$ & $75.85 \pm 2.54$ & $325 \pm 59$ & $147 \pm 3$ & $230 \pm 13$ & $245 \pm 15$ \\
\hline \multirow{2}{*}{ Low protein diet $+\mathrm{Cd}$} & $136.09 \pm 6.61$ & $71.26 \pm 5.43$ & $81.84 \pm 2.97$ & $105.44 \pm 2.41$ & $206 \pm 7$ & $158 \pm 4$ & $338 \pm 15$ & $314 \pm 16$ \\
\hline & $(\downarrow 15)^{\mathrm{b}} \mathrm{NS}$ & $(\uparrow 19)^{b} \mathrm{NS}$ & $(\uparrow 29)^{b * *}$ & $(\uparrow 39)^{b * * *}$ & $(\downarrow 37)^{\mathrm{b}} \mathrm{NS}$ & $(\uparrow 7)^{\mathrm{b}} \mathrm{NS}$ & $(\uparrow 47)^{\mathrm{b} * * *}$ & $(\uparrow 28)^{b * *}$ \\
\hline
\end{tabular}

Values represent mean \pm SE of six rats; Statistical evaluation by one-way ANOVA followed by LSD comparison;

$a=$ Compared to normal diet control, $b=$ Compared to low protein diet control; $p^{*}=<0.05 ;{ }^{* *}=0.01 ;{ }^{* *}=<0.001$;

$\uparrow=$ increase; $\downarrow$ = decrease, NS = Non-significant.

Table 2: Effect of $\mathrm{Cd}$ on urine levels of acid phosphatase in normal and protein malnourished rats (values in parentheses represent \% change). 
Citation: Husain SS (2013) Studies on Hepato and Renal Toxicity of Cadmium on Normal and Protein Malnourished Rats. J Material Sci Eng 2: 129. doi:10.4172/2169-0022.1000129

Page 3 of 6

\begin{tabular}{|c|c|c|c|c|c|c|c|c|}
\hline \multirow{3}{*}{ Treatment } & \multicolumn{4}{|c|}{$\mathrm{n}$ mole hydrazones formed $/ \mathrm{ml}$ of urine } & \multicolumn{4}{|c|}{ n mole hydrazones formed/ml/day/rat } \\
\hline & \multicolumn{4}{|c|}{ Days } & \multicolumn{4}{|c|}{ Days } \\
\hline & 30 & 60 & 90 & 120 & 30 & 60 & 90 & 120 \\
\hline Normal diet & $31.472 \pm 6.3$ & $24.954 \pm 6.35$ & $20.67 \pm 1.55$ & $22.75 \pm 1.60$ & $127 \pm 12$ & $91 \pm 5$ & $76 \pm 7$ & $80 \pm 6$ \\
\hline \multirow{2}{*}{ Normal diet + Cd } & $38.759 \pm 4.95$ & $46.633 \pm 2.11$ & $28.31 \pm 2.208$ & $31.15 \pm 2.21$ & $173 \pm 33$ & $124 \pm 5$ & $84 \pm 5$ & $112 \pm 7$ \\
\hline & $(\uparrow 23)^{a} \mathrm{NS}$ & $(\uparrow 87)^{\mathrm{a} * *}$ & $(\uparrow 37)^{\mathrm{a} *}$ & $(\uparrow 37)^{\mathrm{a} *}$ & $(\uparrow 36)^{\mathrm{a}} \mathrm{NS}$ & $(\uparrow 36)^{\mathrm{a} * * *}$ & $(\uparrow 11)^{\mathrm{a}} \mathrm{NS}$ & $(\uparrow 40)^{\mathrm{a} *}$ \\
\hline Low protein diet & $25.89 \pm 2.40$ & $20.15 \pm 3.53$ & $20.01 \pm 1.19$ & $21.31 \pm 1.20$ & $63 \pm 13$ & $24 \pm 2$ & $25 \pm 1$ & $30 \pm 3$ \\
\hline \multirow{2}{*}{ Low protein diet $+\mathrm{Cd}$} & $28.18 \pm 43.078$ & $73.078 \pm 3.25$ & $32.196 \pm 3.02$ & $36.456 \pm 3.8$ & $69 \pm 22$ & $56 \pm 6$ & $35 \pm 6$ & $45 \pm 7$ \\
\hline & $(\uparrow 9)^{\mathrm{b}} \mathrm{NS}$ & $(\uparrow 114)^{b * * *}$ & $(\uparrow 60)^{b * * *}$ & $(\uparrow 71)^{b * *}$ & $(\uparrow 10)^{b} \mathrm{NS}$ & $(\uparrow 133)^{b * * *}$ & $(\uparrow 40)^{\mathrm{b} *}$ & $(\uparrow 50)^{b *}$ \\
\hline
\end{tabular}

Values represent mean \pm SE of six rats; Statistical evaluation by one-way ANOVA followed by LSD comparison;

$a=$ Compared to normal diet control, $b=$ Compared to low protein diet control; $p^{*}=<0.05 ;{ }^{* *}=0.01 ;{ }^{* \star}=<0.001$;

$\uparrow=$ increase; NS = Non-significant.

Table 3: Effect of Cd on urine levels of GPT in normal and protein malnourished rats (values in parentheses represent \% change).

\begin{tabular}{|c|c|c|c|c|c|c|c|c|}
\hline \multirow{3}{*}{ Treatment } & \multicolumn{4}{|c|}{$\mathrm{n}$ mole hydrazones formed $/ \mathrm{ml}$ of urine } & \multicolumn{4}{|c|}{ n mole hydrazones formed/ml/day/rat } \\
\hline & \multicolumn{4}{|c|}{ Days } & \multicolumn{4}{|c|}{ Days } \\
\hline & 30 & 60 & 90 & 120 & 30 & 60 & 90 & 120 \\
\hline Normal diet & $31.472 \pm 6.3$ & $24.954 \pm 6.35$ & $20.67 \pm 1.55$ & $22.75 \pm 1.60$ & $127 \pm 12$ & $91 \pm 5$ & $76 \pm 7$ & $80 \pm 6$ \\
\hline \multirow{2}{*}{ Normal diet + Cd } & $38.759 \pm 4.95$ & $46.633 \pm 2.11$ & $28.31 \pm 2.208$ & $31.15 \pm 2.21$ & $173 \pm 33$ & $124 \pm 5$ & $84 \pm 5$ & $112 \pm 7$ \\
\hline & $(\uparrow 23)^{\mathrm{a}} \mathrm{NS}$ & $(\uparrow 87)^{\mathrm{a} * *}$ & $(\uparrow 37)^{\mathrm{a} *}$ & $(\uparrow 37)^{\mathrm{a} *}$ & $(\uparrow 36)^{\mathrm{a}} \mathrm{NS}$ & $(\uparrow 36)^{\mathrm{a} * * *}$ & $(\uparrow 11)^{\mathrm{a}} \mathrm{NS}$ & $(\uparrow 40)^{\mathrm{a} *}$ \\
\hline Low protein diet & $25.89 \pm 2.40$ & $20.15 \pm 3.53$ & $20.01 \pm 1.19$ & $21.31 \pm 1.20$ & $63 \pm 13$ & $24 \pm 2$ & $25 \pm 1$ & $30 \pm 3$ \\
\hline \multirow{2}{*}{ Low protein diet $+\mathrm{Cd}$} & $28.18 \pm 43.078$ & $73.078 \pm 3.25$ & $32.196 \pm 3.02$ & $36.456 \pm 3.8$ & $69 \pm 22$ & $56 \pm 6$ & $35 \pm 6$ & $45 \pm 7$ \\
\hline & $(\uparrow 9)^{b} \mathrm{NS}$ & $(\uparrow 114)^{b * * *}$ & $(\uparrow 60)^{b * * *}$ & $(\uparrow 71)^{\mathrm{b} * *}$ & $(\uparrow 10)^{b} \mathrm{NS}$ & $(\uparrow 133)^{b * * *}$ & $(\uparrow 40)^{\mathrm{b} *}$ & $(\uparrow 50)^{b}$ * \\
\hline
\end{tabular}

Values represent mean \pm SE of six rats; Statistical evaluation by one-way ANOVA followed by LSD comparison;

$a=$ Compared to normal diet control, $b=$ Compared to low protein diet control; $p^{*}=<0.05 ;{ }^{* *}=0.01 ;{ }^{* * *}=<0.001$;

$\uparrow=$ increase; NS = Non-significant.

Table 4: Effect of Cd on urine levels of GOT in normal and protein malnourished rats (values in parentheses represent \% change).

\begin{tabular}{|c|c|c|c|c|c|c|c|c|}
\hline \multirow{3}{*}{ Treatment } & \multicolumn{4}{|c|}{$g / 1$} & \multicolumn{4}{|c|}{ mg/day/rat } \\
\hline & \multicolumn{4}{|c|}{ Days } & \multicolumn{4}{|c|}{ Days } \\
\hline & 30 & 60 & 90 & 120 & 30 & 60 & 90 & 120 \\
\hline Normal diet & $0.942 \pm 0.053$ & $0.962 \pm 0.074$ & $1.015 \pm 0.094$ & $1.002 \pm 0.096$ & $9.690 \pm 0.16$ & $10.013 \pm 0.16$ & $10.50 \pm 0.40$ & $10.60 \pm 0.50$ \\
\hline \multirow{2}{*}{ Normal diet + Cd } & $1.197 \pm 0.084$ & $1.331 \pm 0.087$ & $1.637 \pm 0.094$ & $1.488 \pm 0.098$ & $11.450 \pm 0.29$ & $11.653 \pm 0.380$ & $13.147 \pm 0.563$ & $13.988 \pm 0.68$ \\
\hline & $(\uparrow 27)^{\mathrm{a} * *}$ & $(\uparrow 38)^{a \star \star \star *}$ & $(\uparrow 61)^{a \star \star \star \star}$ & $(\uparrow 49)^{\mathrm{a} * *}$ & $(\uparrow 18)^{\mathrm{a} * * *}$ & $(\uparrow 16)^{\mathrm{a} * \star *}$ & $(\uparrow 25)^{a \star * *}$ & $(\uparrow 32)^{\mathrm{a} * *}$ \\
\hline Low protein diet & $0.532 \pm 0.014$ & $0.552 \pm 0.013$ & $0.57 \pm 0.010$ & $0.546 \pm 0.011$ & $1.053 \pm 0.08$ & $1.050 \pm 0.100$ & $1.106 \pm 0.141$ & $1.155 \pm 0.251$ \\
\hline \multirow{2}{*}{ Low protein diet + Cd } & $0.80 \pm 0.033$ & $0.832 \pm 0.026$ & $0.874 \pm 0.032$ & $0.935 \pm 0.035$ & $1.292 \pm 0.13$ & $1.440 \pm 0.114$ & $1.918 \pm 0.322$ & $1.930 \pm 0.20$ \\
\hline & $(\uparrow 51)^{b * *}$ & $(\uparrow 51)^{b * *}$ & $(\uparrow 54)^{b * *}$ & $(\uparrow 68)^{b * * *}$ & $(\uparrow 23)^{b} \mathrm{NS}$ & $(\uparrow 37)^{\mathrm{b}} \mathrm{NS}$ & $(\uparrow 73)^{b} * *$ & $(\uparrow 69)^{b * * *}$ \\
\hline
\end{tabular}

Values represent mean \pm SE of six rats; Statistical evaluation by one-way ANOVA followed by LSD comparison;

$a=$ Compared to normal diet control, $b=$ Compared to low protein diet control; $p^{* *}=<0.01 ;{ }^{* *}=<0.001$;

$\uparrow=$ increase; NS = Non-significant.

Table 5: Effect of Cd on urine levels of total amino acids in normal and protein malnourished rats (values in parenthesis represent \% change).

\begin{tabular}{|c|c|c|c|c|c|c|c|c|}
\hline \multirow{3}{*}{ Treatment } & \multicolumn{4}{|c|}{$g / 1$} & \multicolumn{4}{|c|}{ mg/day/rat } \\
\hline & \multicolumn{4}{|c|}{ Days } & \multicolumn{4}{|c|}{ Days } \\
\hline & 30 & 60 & 90 & 120 & 30 & 60 & 90 & 120 \\
\hline Normal diet & $1.009 \pm 0.08$ & $2.013 \pm 0.051$ & $2.146 \pm 0.05$ & $2.146 \pm 0.06$ & $7.367 \pm 1.39$ & $7.493 \pm 0.498$ & $10.796 \pm 0.25$ & $10.695 \pm 0.263$ \\
\hline \multirow{2}{*}{ Normal diet + Cd } & $1.594 \pm 0.173$ & $3.133 \pm 0.307$ & $3.679 \pm 0.244$ & $3.671 \pm 0.251$ & $7.734 \pm 1.013$ & $8.372 \pm 0.388$ & $14.019 \pm 0.07$ & $14.00 \pm 0.07$ \\
\hline & $(\uparrow 58)^{\mathrm{a} \star \star}$ & 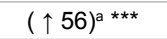 & $(\uparrow 72)^{\mathrm{a} \star \star \star}$ & $(\uparrow 71)^{\mathrm{a} \star \star \star}$ & $(\uparrow 5)^{\mathrm{a}} \mathrm{NS}$ & $(\uparrow 12)^{\mathrm{a}} \mathrm{NS}$ & $(\uparrow 30)^{\mathrm{a} * \star *}$ & $(\uparrow 31)^{\mathrm{a} * \star \star}$ \\
\hline Low protein diet & $0.983 \pm 0.152$ & $1.867 \pm 0.049$ & $1.910 \pm 0.09$ & $1.825 \pm 0.09$ & $3.455 \pm 0.164$ & $2.268 \pm 0.110$ & $4.264 \pm 0.092$ & $4.132 \pm 0.099$ \\
\hline \multirow{2}{*}{ Low protein diet $+\mathrm{Cd}$} & $1.003 \pm 0.060$ & $2.109 \pm 0.151$ & $2.750 \pm 0.060$ & $3.157 \pm 0.063$ & $3.290 \pm 0.269$ & $4.142 \pm 0.48$ & $6.298 \pm 0.12$ & $6.399 \pm 0.13$ \\
\hline & $(\uparrow 2)^{b} N S$ & $(\uparrow 13)^{b}$ NS & $(\uparrow 44)^{b * * *}$ & $(\uparrow 73)^{b * * *}$ & $(\uparrow 5)^{\mathrm{b}} \mathrm{NS}$ & $(\uparrow 83)^{b * *}$ & $(\uparrow 48)^{b * * *}$ & $(\uparrow 55)^{b * * *}$ \\
\hline
\end{tabular}

Values represent mean \pm SE of six rats; Statistical evaluation by one-way ANOVA followed by LSD comparison;

$a=$ Compared to normal diet control, $b=$ Compared to low protein diet control; $p^{* *}=<0.01 ;{ }^{* * *}=<0.001$;

$\uparrow=$ increase; $\downarrow$ = decrease; NS = Non-significant.

Table 6: Effect of $\mathrm{Cd}$ on urine - albumin in normal and protein malnourished rats (values in parentheses represent $\%$ change).

normal diet fed rats. In the protein malnourished group, significant and more marked increase in the daily excretion of alpha-amino acids, albumin, total protein and glucose was observed on the day 90 and 120 of Cd exposure. A statistically non-significant increase was observed in these animals on days 30 and 60 .

\section{Tissue analysis}

Effect on hepatic enzymes: A significant reduction in the activities of GPT, GOT and alkaline phosphatase was observed in the Cd exposed animals of both the dietary groups. The reduction in the GPT activity was more marked in the malnourished rats whereas the reductions 
Page 4 of 6

\begin{tabular}{|c|c|c|c|c|c|c|c|c|}
\hline \multirow{3}{*}{ Treatment } & \multicolumn{4}{|c|}{$\mathrm{g} / 1$} & \multicolumn{4}{|c|}{ mg/day/rat } \\
\hline & \multicolumn{4}{|c|}{ Days } & \multicolumn{4}{|c|}{ Days } \\
\hline & 30 & 60 & 90 & 120 & 30 & 60 & 90 & 120 \\
\hline Normal diet & $1-101 \pm 0.098$ & $2.390 \pm 0.095$ & $2.448 \pm 0.095$ & $2.475 \pm 0.098$ & $7.750 \pm 1.418$ & $7.769 \pm 0.54$ & $11.618 \pm 4.269$ & $11.712 \pm 4.300$ \\
\hline \multirow{2}{*}{ Normal diet + Cd } & $1.868 \pm 0.216$ & $3.537 \pm 0.292$ & $4.297 \pm 0.271$ & $4.583 \pm 0.292$ & $8.204 \pm 1.129$ & $9.322 \pm 0.4$ & $14.286 \pm 0.125$ & $14.685 \pm 0.130$ \\
\hline & $(\uparrow 70)^{\mathrm{a} * \star}$ & $(\uparrow 48)^{\mathrm{a} * \star *}$ & $(\uparrow 76)^{a * \star \star *}$ & $(\uparrow 85)^{a * * *}$ & $(\uparrow 6)^{\mathrm{a}} \mathrm{NS}$ & $(\uparrow 20)^{a} *$ & $(\uparrow 23)^{a * * \star}$ & $(\uparrow 25)^{\mathrm{a} * \star \star}$ \\
\hline Low protein diet & $1.052 \pm 0.152$ & $2.109 \pm 0.069$ & $2.239 \pm 0.107$ & $2.252 \pm 0.110$ & $3.546 \pm 0.132$ & $2.348 \pm 0.104$ & $4.498 \pm 0.038$ & $4.499 \pm 0.031$ \\
\hline \multirow{2}{*}{ Low protein diet $+\mathrm{Cd}$} & $0.975 \pm 0.071$ & $2.615 \pm 0.159$ & $3.201 \pm 0.102$ & $3.355 \pm 0.104$ & $3.272 \pm 0.251$ & $3.240 \pm 0.211$ & $6.479 \pm 0.132$ & $6.875 \pm 0.130$ \\
\hline & $(\uparrow 7)^{\mathrm{b}} \mathrm{NS}$ & $(\uparrow 24)^{b * *}$ & $(\uparrow 43)^{b * * *}$ & $(\uparrow 49)^{b * * *}$ & $(\uparrow 8)^{b} \mathrm{NS}$ & $(\uparrow 38)^{\mathrm{b} * *}$ & $(\uparrow 44)^{b * * *}$ & $(\uparrow 53)^{b * * *}$ \\
\hline
\end{tabular}

Values represent mean \pm SE of six rats; Statistical evaluation by one-way ANOVA followed by LSD comparison;

$a=$ Compared to normal diet control, $b=$ Compared to low protein diet control; $p^{* *}=<0.01 ;{ }^{* \star *}=<0.001$;

$\uparrow=$ increase; $\downarrow$ = decrease; NS = Non-significant.

Table 7: Effect of $\mathrm{Cd}$ on urine levels of protein in normal and protein malnourished rats (values in parentheses represent \% change)

\begin{tabular}{|c|c|c|c|c|c|c|c|c|}
\hline \multirow{3}{*}{ Treatment } & \multicolumn{4}{|c|}{$\mathrm{g} / 1$} & \multicolumn{4}{|c|}{$\mathrm{mg} /$ day/rat } \\
\hline & \multicolumn{4}{|c|}{ Days } & \multicolumn{4}{|c|}{ Days } \\
\hline & 30 & 60 & 90 & 120 & 30 & 60 & 90 & 120 \\
\hline Normal diet & $16.667 \pm 0.715$ & $14.075 \pm 0.223$ & $8.953 \pm 0.371$ & $9.530 \pm 0.36$ & $0.923 \pm 0.166$ & $0.574 \pm 0.017$ & $0.549 \pm 0.056$ & $0.563 \pm 0.045$ \\
\hline \multirow{2}{*}{ Normal diet $+\mathrm{Cd}$} & $18.33 \pm 1.668$ & $26.467 \pm 0.192$ & $16.307 \pm 0.696$ & $17.15 \pm 0.595$ & $1.093 \pm 0.172$ & $0.898 \pm 0.034$ & $0.701 \pm 0.046$ & $0.810 \pm 0.051$ \\
\hline & $(\uparrow 70)^{\mathrm{a} * *}$ & $(\uparrow 48)^{a * * *}$ & $(\uparrow 76)^{\mathrm{a} * * *}$ & $(\uparrow 85)^{a} * * *$ & $(\uparrow 6)^{\mathrm{a}} \mathrm{NS}$ & $(\uparrow 58)^{\mathrm{a} *}$ & $(\uparrow 28)^{a * * *}$ & $(\uparrow 44)^{a * \star *}$ \\
\hline Low protein diet & $15.667 \pm 0.494$ & $12.033 \pm 0.248$ & $9.345 \pm 0.346$ & $11.535 \pm 0.450$ & $0.642 \pm 0.06$ & $0.262 \pm 0.011$ & $0.164 \pm 0.008$ & $0.120 \pm 0.007$ \\
\hline \multirow{2}{*}{ Low protein diet $+\mathrm{Cd}$} & $17.233 \pm 0.719$ & $17.207 \pm 0.184$ & $15.146 \pm 0.431$ & $17.150 \pm 0.500$ & $0.683 \pm 0.031$ & $0.379 \pm 0.005$ & $0.272 \pm 0.003$ & $0.221 \pm 0.004$ \\
\hline & $(\uparrow 10)^{b} \mathrm{NS}$ & $(\uparrow 43)^{\mathrm{b} * * *}$ & $(\uparrow 62)^{\mathrm{b} * * *}$ & $(\uparrow 49)^{\mathrm{b} * \star *}$ & $(\uparrow 6)^{b} \mathrm{NS}$ & $(\uparrow 45)^{\mathrm{b} * *}$ & $(\uparrow 66)^{b * *}$ & $(\uparrow 84)^{\mathrm{b} * * *}$ \\
\hline
\end{tabular}

Values represent mean \pm SE of six rats; Statistical evaluation by one-way ANOVA followed by LSD comparison;

$a=$ Compared to normal diet control, $b=$ Compared to low protein diet control; $p^{* *}=<0.01 ;{ }^{* *}=<0.001$;

$\uparrow=$ increase; $\downarrow$ = decrease; NS = Non-significant.

Table 8: Effect of $\mathrm{Cd}$ on urine levels of glucose in normal and protein malnourished rats (values in parentheses represent \% change).

observed in the alkaline phosphatase and GOT activities were more marked in the normal protein diet fed rats. The reduction in the acid phosphatase activity was not statistically significant in both the diet groups (Table 9).

Effect on renal enzymes: $\mathrm{Cd}$ exposure resulted in a significant reduction in the activities of GPT, GOT and alkaline phosphatase in both the dietary groups. The reduction in alkaline phosphatase activity was more marked in the malnourished rats and the magnitude of the effect GPT and GOT activities was more or less same in both the diet groups (Table 10).

Effect on serum enzymes: A significant increase in the serum GPT, GOT, alkaline phosphatase and acid phosphatase was observed in both the dietary groups. The effect on these enzymes was more marked in the protein malnourished animals (Table 11).

Effect on blood glucose: Cd exposure resulted in a significant increase in blood glucose levels, of more or less equal magnitude, in both the diet groups (Table 12).

Effect on serum albumin: A significant reduction of the same magnitude in serum albumin level was observed in the Cd- exposed animals of both the diet groups (Table 12).

\section{Discussion}

Hepatotoxicity and nephrotoxicity are among the most important manifestations of $\mathrm{Cd}$ exposure and related to the tissue concentration. The uptake, retention and toxicity of Cd greatly depend on the nutritional factors such as dietary proteins [16]. The present study shows that $\mathrm{Cd}$ exposure resulted in a significant retardation in body weight growth and induced enzymuria, proteinuria, aminoaciduria, glycosuria, hepato and renal damages and alteration in metabolism of essential trace elements.
Previous studies have indicated that the release of enzymes in urine after repeated parenteral administration of $\mathrm{Cd}$ to rat may reflect the development of renal damage caused by the accumulation of critical concentration of the metal [17]. Alkaline phosphatase may be particularly sensitive, since it is localized in the brush border of the proximal tubule of the rat, which is the site of $\mathrm{Cd}$ - induced injury [18]. In the present study, the activity and daily excretion of alkaline phosphatase in urine of Cd- exposed rats of both dietary groups were significantly enhanced from day 30 of exposure onwards. These effects were generally more marked in the protein malnourished animals. A significant increase in the urinary excretion of alkaline phosphatase, within $48 \mathrm{hr}$ of commencing Cd treatment has been reported [17] Synthesis of renal Cd-thionein requires $48 \mathrm{hr}$. following exposure to $\mathrm{Cd}$ for maximum induction [19]. Thus in absence of adequate amounts of the binding protein, Cd may interact with some vital cellular components, though the exact mechanism is unknown. In the present finding, protein malnutrition might have contributed towards less synthesis of $\mathrm{Cd}$ - binding protein thionein, owing to the dearth of essential amino acids required for the synthesis. The Cd exposed animals of either dietary group exhibited an enhanced urinary acid phosphatase activity and excretion on days 90 and 120 of exposure and the effect was more marked in the protein malnourished rats. This increase is in conformity with the findings of Nomiyama [15].

Since the serum activities of enzymes were considerably increased, it manifests that this increase in enzyme activities in the urine resulted from enzymes released from injured organs other than the kidneys. Some researchers proved that the increase in enzyme activity in the urine results from the malfunctioning process of re-absorption at the tubules $[20,21]$. In our investigation, liver seemed to be protected from Cd- induced liver infarction till day 60 , as the activity of GPT was found to be increasing in urine only after day 60 of Cd- exposure. Malnourished animals showed more marked effect with decreased 


\begin{tabular}{|c|c|c|c|c|}
\hline \multirow{2}{*}{ Treatment } & \multicolumn{2}{|c|}{$\mathrm{n}$ mole hydrazones formed $/ \mathrm{m} / \mathrm{mg}$ protein } & \multicolumn{2}{|c|}{ n mole $\mathrm{p}$-nitro phenol formed $/ \mathrm{m} / \mathrm{mg}$ protein } \\
\hline & GPT & GOT & Alkaline phosphatase & Acid phosphatase \\
\hline Normal diet & $223.06 \pm 12.25$ & $217.28 \pm 8.32$ & $107.84 \pm 6.02$ & $531.49 \pm 52.10$ \\
\hline \multirow{2}{*}{ Normal diet + Cd } & $175.22 \pm 9.70$ & $190.23 \pm 7.46$ & $64.73 \pm 4.12$ & $452.98 \pm 33.53$ \\
\hline & $(\downarrow 21)^{\mathrm{a} * \star \star}$ & $(\downarrow 12)^{\mathrm{a} *}$ & $(\downarrow 40)^{\mathrm{a} * * \star}$ & $(\downarrow 15)^{\mathrm{a}} \mathrm{NS}$ \\
\hline Low protein diet & $74.76 \pm 5.37$ & $218.75 \pm 8.76$ & $108.56 \pm 4.26$ & $673.23 \pm 59.49$ \\
\hline \multirow{2}{*}{ Low protein diet $+\mathrm{Cd}$} & $48.03 \pm 2.55$ & $207.54 \pm 5.39$ & $76.58 \pm 0.41$ & $599.11 \pm 42.86$ \\
\hline & $(\downarrow 36)^{b} *$ & $(\downarrow 5)^{\mathrm{b}} \mathrm{NS}$ & $(\downarrow 29)^{b * * *}$ & $(\downarrow 11)^{\mathrm{b}} \mathrm{NS}$ \\
\hline
\end{tabular}

Values represent mean \pm SE of six rats; Statistical evaluation by one-way ANOVA followed by LSD comparison;

$a=$ Compared to normal diet control, $b=$ Compared to low protein diet control; $p^{* *}=<0.05 ;{ }^{* * *}=<0.01$;

$\downarrow=$ decrease; NS = Non-significant.

Table 9: Effect of Cd exposure (120 days) on hepatic enzyme activity in normal and protein malnourished rats (values in parentheses represent \% change).

\begin{tabular}{|c|c|c|c|c|}
\hline \multirow{2}{*}{ Treatment } & \multicolumn{2}{|c|}{$\mathrm{n}$ mole hydrazones formed $/ \mathrm{m} / \mathrm{mg}$ protein } & \multicolumn{2}{|c|}{$\mathrm{n}$ mole $\mathrm{p}$-nitro phenol formed $/ \mathrm{m} / \mathrm{mg}$ protein } \\
\hline & GPT & GOT & Alkaline phosphatase & Acid phosphatase \\
\hline Normal diet & $33.80 \pm 0.75$ & $38.90 \pm 0.64$ & $392.17 \pm 38.19$ & $88.74 \pm 6.72$ \\
\hline \multirow{2}{*}{ Normal diet + Cd } & $30.60 \pm 0.10$ & $35.33 \pm 0.59$ & $454.91 \pm 40.31$ & $83.98 \pm 10.61$ \\
\hline & $(\downarrow 8)^{\mathrm{a} * \star *}$ & $(\downarrow 9)^{\mathrm{a} * *}$ & $(\downarrow 16)^{\mathrm{a} *}$ & $(\downarrow 5)^{\mathrm{a}} \mathrm{NS}$ \\
\hline Low protein diet & $36.92 \pm 1.01$ & $43.74 \pm 0.58$ & $520.31 \pm 44.0$ & $119.41 \pm 9.83$ \\
\hline \multirow{2}{*}{ Low protein diet $+\mathrm{Cd}$} & $33.01 \pm 0.65$ & $40.98 \pm 0.80$ & $660.793 \pm 43.65$ & $116.05 \pm 17.06$ \\
\hline & $(\downarrow 11)^{\mathrm{b} * *}$ & $(\downarrow 6)^{\mathrm{b} * *}$ & $(\downarrow 27)^{\mathrm{b} * *}$ & $(\downarrow 3)^{\mathrm{b}} \mathrm{NS}$ \\
\hline
\end{tabular}

Values represent mean \pm SE of six rats; Statistical evaluation by one-way ANOVA followed by LSD comparison;

$a=$ Compared to normal diet control, $b=$ Compared to low protein diet control; $p^{* *}=<0.05 ;{ }^{* * *}=<0.01$;

$\downarrow=$ decrease; NS = Non-significant.

Table 10: Effect of Cd exposure (120 days) on renal enzyme activity in normal and protein malnourished rats (values in parentheses represent \% change).

\begin{tabular}{|c|c|c|c|c|}
\hline \multirow{2}{*}{ Treatment } & \multicolumn{2}{|c|}{$\mathrm{n}$ mole hydrazones formed $/ \mathrm{m} / \mathrm{mg}$ protein } & \multicolumn{2}{|c|}{$\mathrm{n}$ mole $\mathrm{p}$-nitro phenol formed $/ \mathrm{m} / \mathrm{mg}$ protein } \\
\hline & GPT & GOT & Alkaline phosphatase & Acid phosphatase \\
\hline Normal diet & $32.44 \pm 1.32$ & $90.39 \pm 1.08$ & $43.07 \pm 1.23$ & $40.35 \pm 0.49$ \\
\hline \multirow{2}{*}{ Normal diet + Cd } & $50.79 \pm 0.56$ & $108.92 \pm 0.86$ & $55.75 \pm 2.19$ & $45-14 \pm 1.45$ \\
\hline & $(\uparrow 57)^{\mathrm{a} * * *}$ & $(\uparrow 9)^{a * \star}$ & $(\uparrow 16)^{\mathrm{a} *}$ & $(\uparrow 5)^{\mathrm{a}} \mathrm{NS}$ \\
\hline Low protein diet & $30.56 \pm 1.22$ & $83.25 \pm 2.23$ & $40.86 \pm 1.71$ & $39.73 \pm 0.52$ \\
\hline \multirow{2}{*}{ Low protein diet $+\mathrm{Cd}$} & $56.89 \pm 1.67$ & $123.59 \pm 2.17$ & $63.10 \pm 1.02$ & $58.45 \pm 1.98$ \\
\hline & $(\uparrow 86)^{b * \star *}$ & $(\uparrow 48)^{\mathrm{b} * * *}$ & $(\uparrow 54)^{b * * *}$ & $(\uparrow 47)^{\mathrm{b} * \star *}$ \\
\hline
\end{tabular}

Values represent mean \pm SE of six rats; Statistical evaluation by one-way ANOVA followed by LSD comparison;

$a=$ Compared to normal diet control, $b=$ Compared to low protein diet control; $p^{* *}=<0.05 ;{ }^{* * *}=<0.01$;

$\downarrow=$ decrease; NS = Non-significant.

Table 11: Effect of Cd exposure (120 days) on Serum enzyme activity in normal and protein malnourished rats (values in parentheses represent \% change).

\begin{tabular}{|c|c|c|}
\hline \multirow{2}{*}{ Treatment } & $\mathrm{mg} / \mathrm{dl}$ & $\mathrm{g} / \mathrm{d} 1$ \\
\hline & Blood glucose & Serum albumin \\
\hline Normal diet & $38.470 \pm 0.59$ & $3.776 \pm 0.05$ \\
\hline \multirow{2}{*}{ Normal diet + Cd } & $50.773 \pm 1.25$ & $3.383 \pm 0.04$ \\
\hline & $(\uparrow 32)^{\mathrm{a} * \star \star}$ & $(\downarrow 10)^{\mathrm{a} * * *}$ \\
\hline Low protein diet & $42.833 \pm 2.15$ & $3.303 \pm 0.03$ \\
\hline \multirow{2}{*}{ Low protein diet $+\mathrm{Cd}$} & $54.609 \pm 1.43$ & $2.954 \pm 0.09$ \\
\hline & $(\uparrow 27)^{\mathrm{b} * * *}$ & $(\downarrow 11)^{\mathrm{b} * \star \star}$ \\
\hline
\end{tabular}

Values represent mean \pm SE of six rats; Statistical evaluation by one-way ANOVA followed by LSD comparison;

$\mathrm{a}=$ Compared to normal diet control, $\mathrm{b}=$ Compared to low protein diet control; $\mathrm{p}^{* *}=<0.05 ;{ }^{* * *}=<0.01$;

$\uparrow=$ increase; $\downarrow$ = decrease

Table 12: Effect of Cd exposure (120 days) on Serum enzyme activity in normal and protein malnourished rats (values in parentheses represent \% change).

rate of detoxification by Cd- thionein. Another most probable cause of enzymuria seems to be the release of enzymes from destroyed tubular cell which are rich in enzymes such as ALP, GOT and GPT. This observation is supported by the fact that renal tissue levels of ALP, GOT and GPT decreased significantly in Cd exposed rats of either dietary group. The significant inhibition in the activities of renal GOT and GPT upon Cd feeding is an indication of Cd nephrotoxicity [22]. High acid and alkaline phosphatase activities have been reported in rats fed on protein deficient diets [23]. It is highly probable that increase in alkaline phosphatase contributes to retardation of growth in malnourished animals.

We found that the urinary concentration of amino acids was significantly enhanced in the Cd exposed animals of both the dietary groups, from day 30 of exposure onwards, but the effect was more marked in the protein malnourished animals. The daily excretion was also significantly enhanced from day 30 to 120 of Cd exposure in the normal diet fed rats. In the protein malnourished group, significant and more marked increase in the daily excretion of amino acid was 
observed on the day 90 and 120 of Cd exposure. The present data may suggest that the critical concentration of cadmium in the renal cortex is lower for aminoaciduria than for proteinuria or glycosuria. Cd caused a dysfunction in amino acid nitrogen metabolism, such as increased glutamic acid metabolism, decreased urea synthesis and decreased ammonium formation have also been supported by previous finding [24]. On the basis of experiments on rabbits given subcutaneous injection of $\mathrm{CdCl}_{2}$ at $1.5 \mathrm{mg} \mathrm{Cd} / \mathrm{kg}$ for 21 days, results showed aminoaciduria might be caused by disturbed tubular re-absorption of amino acids due to the increased clearance ratio of amino acids to creatinine [15]. The daily excretion of proteins in urine was also significantly enhanced from day 60 of $\mathrm{Cd}$ exposure in both the dietary groups, but the effect was more marked in protein malnourished animals.

In recent years, glomerular dysfunctions have been reported to be more prominent than tubular dysfunction in Cd intoxication $[25,26]$. The main protein components in urine of human beings and animals exposed to Cd were large molecular weight protein such as albumin; low molecular weight proteins were minor components, although they are specific for tubular disease. A decrease in protein intake leads to a rise in protein catabolism in liver [27] along with an increase in its hydrolytic activity. This supports the decreased levels of total protein and albumin in urine of protein malnourished rats.

Thus, the present study manifests that exposure to even low dose levels of $\mathrm{Cd}$, coupled with protein under-nutrition increases the risk of environmental exposure of cadmium to man.

\section{References}

1. Murata KJ, Friedman I, Gleason JD (1977) Oxygen isotope relations between diagenetic silica minerals in Monterey Shale, Temblor Range, California. Am J Sci 277: 259-272.

2. Wilson RH, Deeds F, Cox AJ (1941) Effects of continued cadmium feeding. J Pharmacol Exp Ther 71: 222-235.

3. Stowe HD, Wilson M, Goyer RA (1972) Clinical and morphologic effects of oral cadmium toxicity in rabbits. Arch Pathol 94: 389-405.

4. Fox MRS (1976) Cadmium metabolism - a review of aspects pertinent to evaluating dietary cadmium intake by man. Trace Elements in Human Health and Disease. (Vol 2), Academic Press, New York, USA.

5. Friberg L, Piscator M, Nordberg G (1971) Cadmium in the Environment. CRC Press, Cleveland, OH, USA.

6. Ognjanović BI, Marković SD, Ethordević NZ, Trbojević IS, Stajn AS, et al. (2010) Cadmium-induced lipid peroxidation and changes in antioxidant defense system in the rat testes: protective role of coenzyme $Q(10)$ and vitamin E. Reprod Toxicol 29: 191-197.

7. Fernández-Pérez B, Caride A, Cabaleiro T, Lafuente A (2010) Cadmium effects on $24 \mathrm{~h}$ changes in glutamate, aspartate, glutamine, GABA and taurine content of rat striatum. J Trace Elem Med Biol 24: 212-218.

8. Chater S, Douki T, Favier A, Sakly M, Abdelmelek H (2009) Changes in antioxidant status and biochemical parameters after orally cadmium administration in females rats. Acta Biol Hung 60: 79-88.
9. Webb DR (1975) Letter: Pulmonary fibrosis and dermatomyositis. JAMA 234: 1018-1019.

10. Uchida H, Kurata Y, Hiratsuka H, Umemura T (2010) The effects of a vitamin D-deficient diet on chronic cadmium exposure in rats. Toxicol Pathol 38: 730 737.

11. Axelsson B, Piscator M (1966) Renal damage after prolonged exposure to cadmium. An experimental study. Arch Environ Health 12: 360-373.

12. Nomiyama K, Sugata Y, Yammoto A, Nomiyama H (1975) Effects of dietary cadmium on rabbits. I. Early signs of cadmium intoxication. Toxicol Appl Pharmacol 31: 4-12.

13. Prigge $E$ (1978) Early signs of oral and inhalative cadmium uptake in rats. Arch Toxicol 40: 231-247.

14. berlin H, Berlin R, Brante G, Sjoberg SG (1958) Studies on intrinsic factor and pernicious anemia. I. Oral uptake of vitamin B12 in pernicious anemia with increasing doses of an intrinsic factor concentrate. Scand J Clin Lab Invest 10: $278-282$

15. Nomiyama K, Sato C, Yamamoto A (1973) Early signs of cadmium intoxication in rabbits. Toxicol Appl Pharmacol 24: 625-635.

16. Fox MR (1979) Nutritional influences on metal toxicity: cadmium as a model toxic element. Environ Health Perspect 29: 95-104.

17. Bonner FW, King LJ, Parke DV (1980) The urinary excretion of alkaline phosphatase after the repeated parenteral administration of cadmium to rats given a high dietary supplement of zinc. Toxicol Lett 6: 369-372.

18. Stroo WE, Hook JB (1977) Enzymes of renal origin in urine as indicators of nephrotoxicity. Toxicol Appl Pharmacol 39: 423-434.

19. Cempel M, Webb M (1976) The time-course of cadmium-thionein synthesis in the rat. Biochem Pharmacol 25: 2067-2071.

20. Crockson RA (1961) Lactic dehydrogenase in renal disease. Urinary concentrations and relative clearances. Lancet 1: 140-142.

21. Hayslett JP, Perillie PE, Finch SC (1968) Urinary muramidase and renal disease. Correlation with renal histology and implication for the mechanism of enzymuria. N Engl J Med 279: 506-512.

22. Tewari PC, Kachru DN, Tandon SK (1986) Influence of copper and iron on subacute cadmium intoxication in protein-malnourished rats. Environ Res 41 : 53-60.

23. Roobol A, Alleyne GA (1974) Changes in lysosomal hydrolase activity associated with malnutrition in young rats. Br J Nutr 32: 189-197.

24. Hoshino T, Tsuchiya K (1976) Kankyo Hoken Rep 38: 189-201.

25. Bernard A, Roels H, Hubermont G, Buchet JP, Masson PL, et al. (1976) Characterization of the proteinuria in cadmium-exposed workers. Int Arch Occup Environ Health 38: 19-30.

26. Nomiyama K, Matsui K, Nomiyama H (1978) Acute toxicity of beryllium in mice at different environmental temperatures. Sangyo Igaku 20: 384-385.

27. Enwonwu CO, Munro HN (1970) Rate of RNA turnover in rat liver in relation to intake of protein. Arch Biochem Biophys 138: 532-539. 